\title{
Anti-inflammatory effects of WFS1 in pancreatic $\beta$-cells
}

$5{ }^{1}$ Department of Medicine, Division of Endocrinology, Metabolism, and Lipid Research,

6 Washington University School of Medicine, St. Louis

$7 \quad{ }^{2}$ Department of Pediatrics, Graduate School of Medicine, Hokkaido University

$8{ }^{3}$ Department of Pathology and Immunology, Washington University School of Medicine, St.

9 Louis

\section{Correspond to:}

12 Fumihiko Urano, $\mathrm{MD}, \mathrm{PhD}$

13 Department of Medicine, Division of Endocrinology, Metabolism, and Lipid Research

14 Washington University School of Medicine, St. Louis MO 63110, USA

15 Email: $\underline{\text { urano@wustl.edu }}$

16

\section{Keywords}

18 Wolfram syndrome, inflammation, diabetes, macrophage, endoplasmic reticulum stress,

19 unfolded protein response 


\section{Abstract}

22 Wolfram syndrome is a rare genetic disorder characterized by juvenile-onset diabetes mellitus,

23 optic nerve atrophy, hearing loss, diabetes insipidus, and progressive neurodegeneration.

24 Pathogenic variants in the WFS1 gene are the main causes of Wolfram syndrome. WFS1 encodes a

25 transmembrane protein localized to the endoplasmic reticulum (ER) and regulates the unfolded

26 protein response (UPR). Loss of function of WFS1 leads to dysregulation of insulin production and

27 secretion, ER calcium depletion, and cytosolic calpains activation, resulting in activation of

28 apoptotic cascades. Although the terminal UPR has been shown to induce inflammation that

29 accelerates $\beta$-cell dysfunction and death in diabetes, the contribution of $\beta$-cell inflammation to the

30 development of diabetes in Wolfram syndrome has not been fully understood. Here we show that

31 WFS1-deficiency enhances the gene expression of inflammatory cytokines and chemokines,

32 leading to cytokine-induced ER-stress and cell death in pancreatic $\beta$-cells. PERK and IRE1 $\alpha$

33 pathways mediate high glucose-induced inflammation in a $\beta$-cell model of Wolfram syndrome.

34 M1-macrophage infiltration and hypervascularization are seen in the pancreatic islets of Wfsl

35 whole-body knockout mice, demonstrating that WFS1 regulates anti-inflammatory responses in

$36 \beta$-cells. Our results demonstrate that inflammation plays an essential role in the progression of

$37 \quad \beta$-cell death and diabetes in Wolfram syndrome and reveal that the pathways involved in ER

38 stress-mediated inflammation provide potential therapeutic targets for the treatment of Wolfram

39 syndrome. 


\section{Introduction}

41 Wolfram syndrome is a rare genetic disorder characterized by juvenile-onset diabetes mellitus,

42 optic nerve atrophy, hearing loss, and progressive neurodegeneration (1-3). Most cases of

43 Wolfram syndrome are caused by pathogenic variants in the WFS1 gene, which encodes a

44 transmembrane protein localized to the endoplasmic reticulum (ER) (4). WFS1 regulates ER

45 calcium homeostasis, and its dysfunction causes the accumulation of unfolded/misfolded

46 proteins in the ER (referred to as ER stress). Pathological ER stress mediates cell death in

47 pancreatic $\beta$-cells and neuronal cells, which is thought to be the mechanism of Wolfram

48 syndrome development (5-7).

50 ER stress occurs even under physiological conditions, as protein folding in the ER is an

51 error-prone process. To maintain cellular and organ homeostasis, the unfolded protein response

52 (UPR) determines the cell's fate by sensing physiological or pathological ER stress (8). The

53 induction of adaptive UPR that leads to cell survival, or the initiation of pathological UPR that

54 leads to cell apoptosis, is regulated by the molecular components of the UPR: inositol-requiring

55 transmembrane kinase/endoribonuclease $1 \alpha(\operatorname{IRE} 1 \alpha)$, protein kinase RNA-like endoplasmic

56 reticulum kinase (PERK), and activating transcription factor 6 (ATF6).

58 Increasing evidence indicates that pathological ER stress causes sterile inflammation, an

59 inflammatory response regulated by the pathological UPR (9). Among the UPR signaling

60 pathways, the IRE1 $\alpha$ pathway is known to degrade I $\kappa \mathrm{B}$, a specific inhibitor of nuclear factor- $\kappa \mathrm{B}$ 
61 (NF- $\mathrm{kB})$, which is a family of transcription factors that regulates the gene expression of

62 pro-inflammatory cytokines (10). In addition, the PERK pathway is known to suppress I $\mathrm{KB}$

63 translation (11). These UPR pathways regulate the nuclear translocation of $\mathrm{NF}-\mathrm{\kappa B}$ and are the

64 molecular mechanisms linking pathogenic ER stress and sterile inflammation (11). Since $\beta$-cells

65 are heavily loaded with protein synthesis and proinsulin is prone to misfold, ER stress is closely

66 associated with the pathogenesis of diabetes (12). Moreover, increasing evidence suggests that

67 ER stress-induced sterile inflammation is involved in the progression of type 2 diabetes (12-14).

68

69 We previously showed that WFS1 dysfunction causes pathological ER stress-mediated $\beta$-cell

70 death (15). However, the role of inflammation in Wolfram syndrome and its relationship with

71 WFS1 has not been fully elucidated. In this study, we hypothesized that pathogenic ER stress

72 and inflammation in $\beta$-cells might accelerate the progression of diabetes in Wolfram syndrome.

73 Our findings reveal islet-localized inflammation in Wolfram syndrome models and suggest that

74 WFS1 functions to regulate sterile inflammation in $\beta$-cells. Supplementing our previous model

75 that shows the relationship between WFS1 and ER stress-induced $\beta$-cell death, here we provide

76 new evidence showing that islet-localized inflammation accelerates the progression of diabetes

77 in Wolfram syndrome. 


\section{Results}

\section{Loss of function of WFS1 induces sterile inflammation in pancreatic $\beta$-cells}

81 To investigate whether WFS1 dysfunction leads to sterile inflammation via pathological ER

82 stress in $\beta$-cells, we first examined apoptosis and pro-inflammatory cytokine gene expression

83 levels in Wfsl knockdown INS-1E cells. In this in vitro Wolfram syndrome model, cleaved

84 caspase-3 levels were increased, suggesting activation of apoptosis (Figure 1A, 1B). Furthermore,

85 the gene expression levels of pro-inflammatory cytokines (Il-1 $\beta, I l-6$, and Cxcll(Il-8)) and Chop

86 were significantly upregulated (Figure 1C). These results indicate that WFS1 plays a role in the

87 regulation of ER stress-mediated cell death and pro-inflammatory cytokine gene expression.

89 Pro-inflammatory cytokine gene expression is enhanced by high-glucose stimulation in

$90 \quad \beta$-cell models of Wolfram syndrome

91 Diabetes, caused by ER stress-mediated pancreatic $\beta$-cell apoptosis, is one of the major and early

92 manifestations of Wolfram syndrome $(1,16)$, suggesting that pancreatic $\beta$-cells of Wolfram

93 syndrome patients are exposed to hyperglycemia for extended time periods. Therefore, we

94 investigated how WFS1-deficient pancreatic $\beta$-cells produce pro-inflammatory cytokines under a

95 chronic high-glucose environment. First, we examined the influence of chronic high-glucose

96 conditions on cell death and ER stress using Wfs1-knockout INS-1 832/13 cells (Wfs1-KO INS-1

97 cells) (Figure $2 \mathrm{~A})$. These $W f s 1-\mathrm{KO}$ INS-1 cells possess the characteristics of pancreatic $\beta$-cells in

98 Wolfram syndrome: thapsigargin intolerance and mitochondrial dysfunction (17) (Figure S1).

99 Wf 1 -KO INS-1 cells treated with high glucose showed elevated proinsulin expression, 
100 caspase-3/7 activity, and gene expression levels of ER stress markers such as Chop, sXbpl, Bip,

101 and Txnip compared to wild type INS-1 832/13 cells (Wfs 1 -WT INS-1 cells), (Figure 2B, 2C,

102 2D). In this condition, the gene expression levels of pro-inflammatory cytokines (Il-1 $\beta, I l-6)$,

103 chemokine $(C c l 2)$, and vascular endothelial growth factor A (VegfA) were increased in $W f_{S} l-\mathrm{KO}$

104 INS-1 cells (Figure 2E). The chronic high-glucose condition enhanced not only the cell apoptosis

105 but also the expression of pro-inflammatory cytokine genes in Wfs 1 -KO INS-1 cells.

107 Cytokine treatment enhances ER stress-mediated cell apoptosis and pro-inflammatory 108 cytokine gene expression in $\boldsymbol{\beta}$-cell models of Wolfram syndrome

109 Pro-inflammatory cytokines secreted from pancreatic $\beta$-cells are known to act in a paracrine or

110 autocrine manner in type 2 diabetes models (18). Therefore, we hypothesized that the locally

111 secreted cytokines might influence the characteristics of pancreatic $\beta$-cells in Wolfram syndrome.

112 To test this idea, we evaluated the cell death and ER stress markers in Wfs 1 -KO INS-1 cells

113 treated with cytokines. Wfs 1 -KO INS-1 treated with IFN- $\gamma$ and IL-1 $\beta$ showed the enhanced ER

114 stress-mediated cell death (Figure 3A). Furthermore, the gene expression levels of $I l-1 \beta, I l-6$, and

$115 C c l 2$ were higher in $W f s 1-K O$ INS-1 cells compared to $W f s 1$-WT INS-1 cells (Figure 3B). These

116 results indicate that cytokine treatment enhances ER stress-mediated cell death and upregulates

117 the pro-inflammatory cytokine gene expression in $W f s l$-deficient $\beta$-cells.

119 High-glucose induced pro-inflammatory cytokine gene expression is mediated by PERK

120 pathway in Wolfram syndrome pancreatic $\boldsymbol{\beta}$-cells 
121 Next, we investigated the mechanisms underlying the upregulation of pro-inflammatory cytokine

122 gene expressions in $W f s 1-\mathrm{KO}$ INS-1 cells. We first examined the protein expression level of

123 nuclear-localized NF- $\mathrm{BB}$, which is known to regulate the expression levels of pro-inflammatory

124 cytokines genes (10). We observed enhanced NF- $\mathrm{BB}$ nuclear translocation in Wfs $1-\mathrm{KO}$ INS-1

125 cells following high-glucose treatment (Figure 4A).

127 We next examined how high-glucose treatment activates the NF- $\kappa$ B pathway. As described

128 above, the downstream pathways of pathological UPR were activated in high-glucose treated

$129 W f_{S}$ 1-KO INS-1 cells, enhancing expression level of ER stress markers such as Txnip. TXNIP is

130 known to activate the NLRP3 inflammasome, which leads to caspase-1 activation and IL-1 $\beta$

131 maturation, and its gene expression is regulated by PERK and IRE1 (19-21). Therefore, to

132 determine whether the pathogenic UPR pathway enhances the NF- $\kappa$ B signaling pathways, we

133 downregulated PERK and IRE1 $\alpha$ in Wfsl-KO INS-1 cells. We found that the PERK was

134 activated at baseline in high-glucose treated $W f s 1$-KO INS-1 cells (Figure 4B). Unlike knocking

135 down IRE1 $\alpha$, knocking down PERK suppressed the enhanced expression of pro-inflammatory

136 cytokine genes in high-glucose treated $W f s 1-K O$ INS-1 cells (Figure 4C, 4D). These results

137 suggest that the induction of pro-inflammatory cytokine gene expressions in high-glucose treated

138 Wfs 1 -KO INS-1 cells was mainly mediated by the PERK pathway and subsequent NF- $\mathrm{BB}$

139 nuclear translocation. The increased Txnip expression in high-glucose treated Wfs 1 -KO INS-1

140 cells was suppressed by simultaneously knocking down PERK and IRE1 $\alpha$ (Figure 4E). These

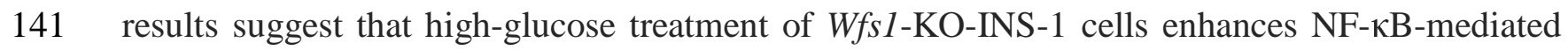


142 pro-inflammatory cytokine genes expression via the PERK pathway and enhances

143 TXNIP-mediated IL-1 $\beta$ processing through the PERK and IRE1 $\alpha$ pathways.

145 Islet-localized and systematic inflammation in the Wolfram syndrome mouse model

146 To confirm the findings above, we next investigated whether inflammation occurs in a mouse

147 model of Wolfram syndrome. Although several WS mouse models have been developed, we

148 used the $W f s 1$ whole-body knockout $129 \mathrm{~S} 6$ mice ( $W f_{s} 1-\mathrm{KO}$ mice) in this study $(15,22)$, which

149 recapitulates human Wolfram syndrome phenotypes and progressively develops glucose

150 tolerance impairment between 4.5 and 6.5 weeks old that persists through at least 10 months of

151 age (15) (Figure S2A, S2B). Based on this knowledge, we collected the pancreatic tissues from

152 mature-adult (16-week-old) and middle-aged (10-month-old) wild type (WT) and Wfs 1 -KO mice

153 and investigated whether macrophages infiltrate the islets. Pancreatic tissue sections from each

154 age were stained with Iba1, a marker for M1/M2 macrophage. Although there were no

155 significant differences in 16-week-old mice, higher Iba1 density was observed in Wfs 1 -KO mice

156 islets at 10 months age-old (Figure 5A, 5B). To further evaluate the character of these

157 islet-resident macrophages, we performed imaging mass cytometry (IMC) on the Wfs 1 -KO mice

158 pancreatic sections. The intra-islet macrophages in $W f s 1-\mathrm{KO}$ mice pancreatic islets expressed

159 CD68 and IL-1 $\beta$, indicating inflammatory M1-like characteristics (Figure 5C). There was also

160 strong fibrosis in the islets of $W f s 1-\mathrm{KO}$ mice (Figure 5D, 5E), previously described as the

161 hallmark of chronic inflammation in the diabetic islets (23). Together, these findings indicate the

162 presence of inflammation in the $W f_{s} 1-\mathrm{KO}$ mice islets. 
164 To examine whether the inflammation was also present in other tissues, we assessed cytokine

165 levels in serum and bone marrow-derived macrophages of $W f s 1$-KO mice. Serum cytokine levels,

166 notably interferon gamma-induced protein 10 (IP-10, CXCL10) was elevated in Wfs 1 -KO mice

167 (Figure S3). These results suggest that the inflammation in these $W f s 1-\mathrm{KO}$ mice was not limited

168 to the pancreatic islets. Although the high-glucose condition did not alter the gene expression

169 levels of pro-inflammatory cytokines in bone marrow-derived macrophages (Figure S4A, S4B),

170 advanced glycation end products (AGE) treatment enhanced Ccl2 gene expression in bone

171 marrow-derived macrophages of $W f s 1$-KO mice (Figure S4C, S4D).

172

\section{Hypervascularization in Wolfram syndrome mouse model islets}

174 In $W f s 1-K O$ INS-1 cells, we observed that high-glucose treatment enhanced VegfA gene

175 expression (Figure 2E). VEGFA, an angiogenic factor, is expressed in the mouse islet and

176 regulates vascular growth and permeability (24-26). Therefore, we tested if increased VEGFA

177 expression may cause abnormal angiogenesis in the pancreatic islets of $W f_{s} 1-\mathrm{KO}$ mice. We

178 evaluated the endothelial cell marker (CD31) in the pancreas of WT and Wfs1-KO mice. A

179 higher CD31 signal density was observed in Wfs1-KO mice islets compared to WT mice islets

180 (Figure 6A, 6B). These results indicate the existence of hypervascularization in the islets of 181 Wf 1 -KO mice. 


\section{Discussion}

184 Although the relationship between the ER stress and pancreatic $\beta$-cell death in Wolfram

185 syndrome has been well established, the role of inflammation in the development of Wolfram

186 syndrome remains unknown. This study provides the first evidence indicating that high-glucose

187 and cytokine treatment activate inflammation in $\beta$-cell and mouse models of Wolfram syndrome.

188 We also confirmed the cell-nonautonomous pancreatic $\beta$-cell inflammation, including

189 M1-macrophage infiltration in the islets of a mouse model of Wolfram syndrome. In pancreatic

$190 \beta$-cells, ER stress and high-glucose conditions enhance the production and secretion of IL-1 $\beta$,

191 which is characteristic of sterile inflammation $(19,27)$. Our data demonstrate that the

192 vulnerability to high-glucose and high-cytokine conditions potentiates ER stress and

193 pro-inflammatory cytokine gene expression in WFS1-deficient pancreatic $\beta$-cells. This

194 environment leads to pancreatic $\beta$-cell death, and the consequent chronic hyperglycemia induces

195 sterile inflammation in WS, causing further pancreatic $\beta$-cell loss. This vicious cycle of

196 inflammation and ER stress may accelerate the progression of diabetes in Wolfram syndrome

197 (Figure 7).

199 The islet-resident macrophages originated from hematopoietic stem cells and are present at

200 steady state conditions (28). However, the density of islet-resident macrophages is known to

201 increase in patients with type 2 diabetes and rat and mouse models of type 2 diabetes (29, 30).

202 These islet-resident macrophages express an M1-like transcript signature, and the macrophages

203 infiltrated into the islets trigger subsequent autoimmune responses (30-32). In this study, we 
204 show that pancreatic islets in $W f s 1-\mathrm{KO}$ mice were highly infiltrated with inflammatory

205 M1-macrophages. Therefore, islet-localized inflammation, which has been shown in the type 2

206 diabetes models, is also present in cell and mouse models of Wolfram syndrome.

208 Circulating macrophages are known to infiltrate tissues and differentiate into tissue-resident

209 macrophages (33). There are two possible reasons for the increased density of islet-resident

210 macrophages in the Wolfram syndrome mouse model. First, macrophages may respond to

211 cytokines and chemokines that are thought to be secreted from islets, as shown by previous

212 studies (30). Our results show that $\beta$-cell model of Wolfram syndrome under hyperglycemia

213 expresses a higher level of $C c l 2$ mRNA compared to the wild type cells. Furthermore, previous

214 studies have reported that the recruitment of circulating macrophages to the islets is dependent

215 on CCL2/CCR2 $(29,34)$. The second possible reason for the high macrophage infiltration is the

216 increased angiogenesis observed in the Wolfram syndrome model mice islets. In this study, we

217 show that VegfA mRNA expression level was increased in WFS1-deficient $\beta$-cells. VEGF-A

218 produced in pancreatic islets plays a critical role in islet angiogenesis (26), and we have

219 previously shown that VEGF-A transcription is regulated by the UPR pathway (35).

220 Islet-resident macrophages and blood vessels are in close contact, and chronic islet

221 hypervascularization leads to progressive macrophage infiltration $(25,36)$. WFS1-deficient cells

222 are vulnerable to ER stress, which promotes VegfA expression, which may lead to

223 hypervascularization and macrophage infiltration in the WS model mice islets. Further studies 
224 are needed to clarify whether intra-islet macrophages are proliferating or whether monocytes are

225 recruited into the islets.

227 A high-glucose environment is known to induce pro-inflammatory cytokine and chemokine 228 genes in macrophages (37). However, in this study, we show that the expression levels of

229 pro-inflammatory cytokine genes in high-glucose treated bone marrow-derived macrophages

230 were not altered by WFS1 deficiency. These results indicate that the functional contribution of

231 WFS1 in the macrophages is not as significant as in the pancreatic $\beta$-cells, possibly because the

232 expression level of WFS1 is lower in macrophages than in the other organs

233 (https://www.proteinatlas.org/ENSG00000109501-WFS1). On the other hand, Wfsl-deficient

234 bone marrow-derived macrophages stimulated with AGE showed an increased expression level

235 of the Ccl2 gene, a marker of M1 macrophages. Since AGE serum levels in Wolfram syndrome

236 model mice increased with age, it is possible that stimulating factors other than blood glucose,

237 including AGE, alter the transcript signature of macrophages in a model of Wolfram syndrome.

239 In type 2 diabetes, elevated levels of serum pro-inflammatory cytokines such as IL-1 $\beta$ and IL-6

240 are predictive disease markers $(14,38,39)$. In this study, we showed that inflammatory cytokine

241 levels in the serum of a mouse model of Wolfram syndrome are higher than that of wild type

242 mice. This result is consistent with the recent studies that showed elevated cytokine levels in WS

243 patient serum and elevated cytokine production in peripheral blood mononuclear cells (PBMC)

244 isolated from Wolfram syndrome patients $(40,41)$. The source of the elevated serum cytokines in 
245 Wolfram syndrome is still unknown; however, since the pancreatic islets are highly vascularized,

246 systemic inflammation may affect the islet inflammation. It is essential to investigate the

247 contribution to the systematic inflammation in Wolfram syndrome by other tissues and organs

248 such as adipose tissue, liver, and blood cells other than macrophages, which are involved in the

249 inflammation associated with type 2 diabetes. Cells or tissues differentiated from patient-derived

250 iPSCs would provide a better model to study the role of inflammation in Wolfram syndrome

253 Besides the Wolfram syndrome $\beta$-cells, sterile inflammation occurs in many other cell types such

254 as oligodendrocytes, hepatocytes, and adipocytes, where the ER is heavily loaded with proteins

255 (9). Symptoms seen in Wolfram syndrome are accompanied not only by diabetes but also by

256 optic nerve atrophy and neurodegeneration, whose pathogenic mechanisms are not fully

257 understood. Therefore, this study suggests that the metabolic factors, including hyperglycemia,

258 inflammatory cytokines, and AGE, may contribute to the progression of Wolfram syndrome

259 symptoms in a cell-nonautonomous manner.

261 In summary, our study identifies sterile inflammation as a new pathological mechanism in the

262 Wolfram syndrome. In Wolfram syndrome model mice, islets are highly infiltrated with

263 macrophages, suggesting that the vicious cycle of ER stress and inflammation accelerates the

264 progression of diabetes in a cell-autonomous and cell-nonautonomous manner. A deeper

265 understanding of the pathophysiology of Wolfram syndrome is important for developing novel 
266 therapeutic targets for the disease. As the inflammation-targeted therapies have been tried in type

2672 diabetes (43), the findings from this study may also be applicable not only to diabetes in

268 Wolfram syndrome but also to other manifestations such as optic atrophy and neurodegeneration,

269 which severely impair the quality of life of patients with Wolfram syndrome. 


\section{Cell culture}

273 Wfs 1 -KO INS-1 832/13 cells were generated in collaboration with Genome Engineering and 274 Induced Pluripotent Stem Cell Center (GEiC) at Washington University in St. Louis as described

275 before (17). INS-1 832/13 cells were cultured in $11 \mathrm{mM}$ glucose RPMI 1640 (Thermo Fisher

276 Scientific, Cat\# 11875) supplemented with 10\% fetal bovine serum (FBS) (Thermo Fisher

277 Scientific, Cat\# 10099141), $1 \mathrm{mM}$ sodium pyruvate (Corning, Cat\# 25-000-CI), $90 \mu \mathrm{M}$

$278 \beta$-mercaptoethanol (MilliporeSigma, Cat\# M3148) and $100 \mathrm{U} / \mathrm{mL}$ penicillin-streptomycin

279 (Thermo Fisher Scientific, Cat\# 15140122). INS-1E cells were cultured in $11 \mathrm{mM}$ RPMI 1640

280 supplemented with $10 \% \mathrm{FBS}, 1 \mathrm{mM}$ sodium pyruvate, $50 \mu \mathrm{M} \beta$-mercaptoethanol, $2 \mathrm{mM}$

281 GlutaMAX (Thermo Fisher Scientific, Cat\# 35050061), NEAA (Thermo Fisher Scientific, Cat\#

282 11140050), 10 mM HEPES (Corning, Cat\# 25-060-CI), and $100 \mathrm{U} / \mathrm{mL}$ penicillin-streptomycin.

283 Rat IFN- $\gamma$, rat IL-1 $\beta$ (R\&D Systems, Cat\# 585-IF-100, 501-RL-010), and thapsigargin

284 (MilliporeSigma, Cat\# T9033) were used for the treatments.

286 Wolfram syndrome mouse model and pancreatic sample preparation

287 129S6 whole body Wfs 1 -knockout mice were a kind gift from Dr. Sulev Kõks (University of

288 Tartu) (22). Amino acids 360-890 of WFS1 protein were replaced with an in $\square$ frame

289 NLSLacZNeo cassette. Mouse genotypes were determined using multiplex PCR performed by

290 Transnetyx (Cordova, TN). All animal experiments were performed according to procedures 
291 approved by the Institutional Animal Care and Use Committee at the Washington University

292 School of Medicine (Protocol \# 20-0334). All mice were housed in a pathogen-free animal

293 facility, and food and water were provided ad libitum throughout the study. For the pancreatic

294 section slides, 129S6 whole body Wfsl-knockout mice were euthanized in a carbon dioxide

295 chamber followed by cervical dislocation. The mice were perfused with PBS and 4\%

296 paraformaldehyde (PFA) via the left ventricle. After perfusion, the pancreas was removed and

297 fixed again with $4 \%$ PFA for $48 \mathrm{~h}$ at $4^{\circ} \mathrm{C}$. The fixed pancreas was gradually replaced by ethanol

298 and finally kept in $70 \%$ ethanol. Paraffin embedding and sectioning were performed by

299 Histology and Morphology Core at Musculoskeletal Research Center at Washington University

300 in St. Louis. Slides were sectioned at $5 \mu \mathrm{m}$ thickness. Microscopy imaging was performed using

301 a Leica DM6B (Leica Microsystems, Germany). All quantitative analyses were conducted using

302 Fiji ImageJ in a double-blinded fashion.

303

304 Immunostaining

305 Paraffin-embedded pancreatic section slides were deparaffinized, and antigen retrieval was

306 performed by submerging the slides in $10 \mathrm{mM}$ sodium citrate solution ( $\mathrm{pH}$ 6.0) for 30 min at

$30795{ }^{\circ} \mathrm{C}$. The tissues were permeabilized with phosphate buffer saline (PBS) containing $0.1 \%$

308 Triton X-100 for $30 \mathrm{~min}$ at room temperature. For the DAB stained samples, endogenous

309 peroxidase was quenched using BLOXALL Blocking solution (VECTOR, Cat\# SP-6000).

310 Blocking was performed in $2 \%$ bovine serum albumin (BSA) for $1 \mathrm{~h}$. The following primary

311 antibodies were diluted in $0.2 \%$ BSA and incubated overnight at $4{ }^{\circ} \mathrm{C}$ : anti-WFS1 (Proteintech, 
312 Cat\# 1158-1-AP, 1:100), anti-Iba1 (Novus, Cat\# NB100-1028, 1:50), anti-CD31 (abcam, Cat\#

313 ab124432, 1:100), and Alexa-Fluor 488 conjugated anti-insulin (Invitrogen, Cat\# 53-9769-82,

314 1:100). After washing the primary antibodies 3 times with PBS, the tissues were incubated for 30

315 min at room temperature with ImmPRESS polymer reagent (VECTOR, Cat\# MP-7401-50) for

316 DAB staining, or AlexaFluor 594 donkey anti-rabbit IgG (Invitrogen, Cat\# A21207) for

317 immunofluorescent staining, and washed for 2 times with PBS. The color development for DAB

318 staining was performed using peroxidase substrate solution (VECTOR, Cat\# SK-4100) following

319 the manufacturer's protocol, and then the nucleus was stained by Vector Hematoxylin QS

320 (VECTOR, Cat\# H-3404). Tissues were mounted in Vectamount permanent mounting medium

321 (VECTOR, Cat\# H5000-60).

323 Masson's trichrome staining

324 Deparaffinized and rehydrated slides were immersed in Bouin's solution at $56^{\circ} \mathrm{C}$ for $1 \mathrm{~h}$.

325 Subsequently, the slides were washed with tap water for $5 \mathrm{~min}$. The washed sections were

326 stained in Weigert's Hematoxylin solution for $10 \mathrm{~min}$ and then washed again with tap water for 5

327 min. Next, the slides were stained in Trichrome solution for $15 \mathrm{~min}$ and rinsed in $1 \%$ acetic acid

328 for 1 min. Slides were dehydrated in alcohol twice for $1 \mathrm{~min}$ each, and sections were cleared in

329 xylene twice for 1 min each. All the Masson's trichrome staining procedures were performed by

330 the Musculoskeletal Research Center at Washington University in St. Louis. 
333 The antibody staining on formalin-fixed paraffin-embedded (FFPE) mouse pancreatic tissue was

334 performed based on Fluidigm immunohistochemistry protocol. Briefly, the FFPE slides were

335 deparaffinized followed by antigen retrieval using $10 \mathrm{mM}$ sodium citrate ( $\mathrm{pH}$ 6.0) for $30 \mathrm{~min}$ at

$33696^{\circ} \mathrm{C}$. Blocking was performed using metal-free $3 \% \mathrm{BSA}$ for 45 min prior to the addition of the

337 primary antibody solution. The primary antibodies were anti-F4/80(BM8) (Fluidigm, Cat\#

338 3146008B), anti-CD68(FA-11) (Biolegend, Cat\# 137001), anti-CD163(EPR19518) (Abcam,

339 Cat\# ab182422), and anti-IL-1ß/IL-1F2(Novus Biologicals, Cat\# NBP1-42767). Metal

340 conjugation was performed using MAXPAR® X8 Multimetal Labeling Kit (Fluidigm, Cat\#

341 201300), and all the antibodies were used in a 1:25 dilution. After overnight incubation of the

342 antibody mixture at $4{ }^{\circ} \mathrm{C}$ in a humidity chamber, the slide was washed with $0.2 \%$ Triton $\mathrm{X}-100$ in

343 PBS and then stained with $0.0025 \%$ Ruthenium Red for contrast staining. After the contrast

344 staining, DNA intercalator for nuclear identification was added. The slides were washed in

345 distilled water and then air-dried before imaging. Antibody conjugation and CyTOF2/Helios

346 imaging were performed by the Immunomonitoring Laboratory (IML) in Bursky Center for

347 Human Immunology \& Immunotherapy Programs (CHiiPs) at Washington University in St.

348 Louis. Optimization of the multiplex panel involves assessing dual signal spillover into $+1,+2$,

349 and +16 channels and lack of signal (false negative). Assessment of signal in other channels was

350 performed using MCD Viewer software and generating a thumbnail image file for each metal

351 channel. The imaging data were converted to TIFF images using HistoCAT++ (ver 3.0.0), and

352 CellProfiler (ver 4.1.3) was used for the cell masking. Image visualization and data analysis were

353 performed using HistoCAT (ver 1.761). 


\section{Cell death assay}

356 INS-1 832/13 cells were plated on 96-well flat clear bottom white polystyrene plates (Corning,

357 Cat\# 3610) and treated with or without the indicated reagents. After the treatment,

358 CellTiter-Fluor Cell Viability Assay (Promega, Cat\# G6080) reagent was added directly to cells

359 and incubated for $30 \mathrm{~min}$ in the dark. After the fluorescence measurement, Caspase-Glo 3/7

360 Assay (Promega, Cat\# G8090) reagent was added to the cells and incubated for $30 \mathrm{~min}$.

361 Fluorescence for cell viability and luminescence for caspase-3/7 activity was measured using

362 Infinite M1000 plate reader (Tecan). Caspase-3/7 activity was normalized to cell viability

363 according to the manufacturer's protocol.

\section{Immunoblot}

366 Cells were washed in cold PBS and immediately lysed on ice in Mammalian Protein Extraction

367 Reagent (Thermo Fisher Scientific, Cat\# 78501) supplemented with $1 \mathrm{X}$ cOmplete ${ }^{\mathrm{TM}}$ protease

368 inhibitor cocktail (MilliporeSigma, Cat\# 11873580001) and 1X PhosSTOP ${ }^{\mathrm{TM}}$ phosphatase

369 inhibitor (MilliporeSigma, Cat\# 4906845001) before centrifugation at 15,000 rpm for $10 \mathrm{~min}$ at

$3704^{\circ} \mathrm{C}$. Nuclear and cytoplasmic extraction was performed using NE-PER ${ }^{\mathrm{TM}}$ (Thermo Fisher

371 Scientific, Cat\# 78833) according to the manufacturer's protocol. Protein lysates were prepared

372 using 4x Laemmli sample buffer (Bio-Rad Laboratories, Cat\# 1610747) heated at $60^{\circ} \mathrm{C}$ for 15

373 min. The protein was resolved by SDS-PAGE and transferred to Immobilon-P PVDF membrane

374 (MilliporeSigma, $0.2 \mu \mathrm{m}$ pore size (Cat\# ISEQ20200) for proinsulin and $0.45 \mu \mathrm{m}$ pore size for 
375 others (Cat\# IPVH00010)). For detecting proinsulin, additional fixation and antigen retrieval

376 steps were performed as reported previously (44). The antibodies used for immunoblotting were

377 anti-WFS1 (Proteintech, Cat\# 1158-1-AP), anti-LaminB1 (Proteintech, Cat\# 12987-1-AP), and

378 those purchased from Cell Signaling Technology: anti-cleaved caspase-3 (Cat\# 9664),

379 anti-insulin (Cat\# 8138), anti-pPERK (Cat\# 3179), anti-PERK (Cat\# 3192), anti-IRE1 $\alpha$ (Cat\#

380 32945), anti-NF-кB (Cat\# 8242), anti-GAPDH (Cat\# 2118), anti- $\alpha$-tubulin (Cat\# 2125), and the

381 secondary antibodies conjugated to horseradish peroxidase. Bands were detected by ECL Select

382 (MilliporeSigma, Cat\# RPN2235) and Bio-Rad ChemiDoc MP. Quantitative analyses were

383 conducted using Fiji ImageJ.

\section{Quantitative real-time PCR}

386 Total RNA was extracted from INS-1E, INS-1 832/13, or isolated primary mouse macrophages

387 using RNeasy Mini Kit (Qiagen, Cat\# 74106) and reverse-transcribed using High-Capacity

388 cDNA Reverse Transcription Kits (Thermo Fisher Scientific, Cat\# 4368814). The qPCR was

389 performed in 3-8 replicates for each sample. All the qPCR primer sequences used in this study

390 are listed in Table S1.

392 SiRNA

393 INS-1E or INS-1 832/13 cells were seeded in a 12-well plate and transfected with siRNA using

394 RNAiMAX (Thermo Fisher Scientific, Cat\# 13778150). ON-TARGET plus SMARTpool siRNA

395 was used for knocking down rat Wfsl (Dharmacon, Cat\# L-087932-02). The siRNA against rat 
396 Perk, Irel $\alpha$, and non-targeting siRNA were purchased from MilliporeSigma (rat Perk,

397 SASI_Rn01_00064452; rat Ire1 $\alpha$, SASI_Rn02_00372535; SIC001 for non-targeting). Each

398 siRNA was used in $40 \mathrm{nM}$ concentration, and RNAiMAX was used $1.0 \mu \mathrm{L}$ against 1 pmol of

399 siRNA. The cells were collected for the analysis $48 \mathrm{~h}$ after the siRNA transfection.

400

$401 \quad$ Statistical analysis

402 All statistics were performed using GraphPad Prism 9. Statistical analysis was performed by

403 unpaired two-tailed Student's t-test or one-way ANOVA followed by Tukey's multiple

404 comparisons test. $\mathrm{P}<0.05$ was considered statistically significant. 
$407 \quad$ Figure legends

408 Figure 1. Cell apoptosis and expression of pro-inflammatory cytokine genes are 409 upregulated in $W f$ s 1 -deficient pancreatic $\beta$-cells

410 (A, B) INS-1E cells were transfected with scrambled siRNA (siCont) or siRNA targeting rat

$411 W f_{S 1}$ (siWfs1). WFS1 and cleaved caspase-3 protein expression levels were analyzed by

412 immunoblot. Representative images are shown in (A), and quantitative analysis results are shown

413 in (B) (n=3, normalized to GAPDH). (C) mRNA expression levels of Chop, Il-1 $\beta, I l-6$, and

414 Cxcl1 (Il-8) in INS-1E cells treated with siCont or siWfs1 normalized to $18 s r R N A(\mathrm{n}=5-6)$. Data

415 are shown as mean $\pm \mathrm{SEM}, * \mathrm{P}<0.05, * * \mathrm{P}<0.005, * * * * \mathrm{P}<0.0001$

417 Figure 2. Hyperglycemia upregulates pro-inflammatory cytokine genes expression in

$418 W f$ I-deficient pancreatic $\beta$-cells

419 (A) Immunoblot images of WFS1 in Wfs 1 wild type (WT) and knock-out (KO) INS-1 832/13

420 cells. (B) Left panel: Immunoblot images of proinsulin in WT and KO INS-1 832/13 cells treated

421 with $25 \mathrm{mM}$ glucose for $1 \mathrm{~h}$. Right panel: Proinsulin band intensity was quantified and

422 normalized to tubulin (n=3). (C) Caspase-3/7 activity normalized to cell viability in WT and KO

423 INS-1 832/13 cells treated with $11 \mathrm{mM}$ or $25 \mathrm{mM}$ glucose for $48 \mathrm{~h}$ (n=8). (D) mRNA expression

424 levels of Chop, sXbp1, Bip, and Txnip in WT or KO INS-1 832/13 cells treated with $11 \mathrm{mM}$ or

$42525 \mathrm{mM}$ glucose for $48 \mathrm{~h}(\mathrm{n}=3-5)$, normalized to $18 s r R N A$. (E) The mRNA expression level of $426 \mathrm{Il}-1 \beta, \mathrm{Il}-6, \mathrm{Ccl}$, and VegfA in WT and KO INS-1 832/13 cells treated with $11 \mathrm{mM}$ or $25 \mathrm{mM}$ 
427 glucose for $48 \mathrm{~h}(\mathrm{n}=3-5)$, normalized to 18 srRNA. Data are shown as mean $\pm \mathrm{SEM}, * \mathrm{P}<0.05$, **

$428 \mathrm{P}<0.005, * * * \mathrm{P}<0.001, * * * * \mathrm{P}<0.0001$.

432 (A) Caspase-3/7 activity normalized to cell viability in $W f_{s} 1$ wild type (WT) and knock-out (KO)

433 INS-1 832/13 cells treated with IFN- $\gamma(50 \mathrm{ng} / \mathrm{mL})$ and IL-1 $\beta(50 \mathrm{ng} / \mathrm{mL})$ for $24 \mathrm{~h}(\mathrm{n}=5)$.

434 mRNA expression level of Chop, Il-1 $\beta, I l-6$, and Ccl2 in WT and KO INS-1 832/13 cells treated

435 with IFN- $\gamma(50 \mathrm{ng} / \mathrm{mL})$ and IL-1 $\beta(50 \mathrm{ng} / \mathrm{mL})$ for $24 \mathrm{~h}(\mathrm{n}=6-8)$, normalized to $18 s r R N A$. Data are

436 shown as mean $\pm \mathrm{SEM}, * \mathrm{P}<0.05$, ** $\mathrm{P}<0.005$, *** $\mathrm{P}<0.001$.

438 Figure 4. PERK pathway regulates the high-glucose induced pro-inflammatory gene 439 expression in $\boldsymbol{W} f_{s} \boldsymbol{1}$-deficient pancreatic $\boldsymbol{\beta}$-cells

440 (A) Left panel: Immunoblot images of NF-кB p-65 in the cytosolic or nuclear fraction of Wfs 1 441 wild type (WT) and knock-out (KO) INS-1 832/13 cells. WT and KO INS-1 832/13 cells were 442 treated with $5 \mathrm{mM}$ glucose for $18 \mathrm{~h}$ and then with $25 \mathrm{mM}$ glucose for $30 \mathrm{~min}$. Right panel: The 443 ratio of nuclear and cytosolic $\mathrm{NF}-\kappa \mathrm{B}$ p-65 protein levels $(\mathrm{n}=3)$. (B) Left panel: Immunoblot 444 images of pPERK and PERK. WT and KO INS-1 832/13 cells were treated with $5 \mathrm{mM}$ for $16 \mathrm{~h}$ 445 and then with $25 \mathrm{mM}$ glucose for $24 \mathrm{~h}$. Right panel: pPERK band intensity was quantified and 446 normalized to total PERK ( $\mathrm{n}=3$ ). (C) Immunoblot images of PERK and IRE1 $\alpha$ in WT and KO

447 INS-1 832/13 cells treated with siRNA against Perk or Irel $\alpha$. (D) mRNA expression level of 
$448 \quad I l-1 \beta$ and Il-6 normalized to $18 s r R N A$ in WT or KO INS-1 832/13 cells treated with $11 \mathrm{mM}$ or 25

$449 \mathrm{mM}$ glucose for $30 \mathrm{~h}$ together with siRNA against Perk or Ire $1 \alpha(\mathrm{n}=4-8)(\mathrm{E}) \mathrm{mRNA}$ expression

450 levels of Txnip normalized to 18 srRNA in WT and KO INS-1 832/13 cells treated with $11 \mathrm{mM}$ or

$45125 \mathrm{mM}$ glucose for $6 \mathrm{~h}$ together with siRNA against Irel $\alpha$ and Perk $(\mathrm{n}=4)$. Data are shown in

452 mean $\pm \mathrm{SEM}, * \mathrm{P}<0.05, * * \mathrm{P}<0.005, * * * \mathrm{P}<0.001$

454 Figure 5. Macrophage infiltration and fibrosis in the Wolfram syndrome mouse model

455 islets

456 (A) Iba1 DAB staining of the islets from Wfs 1 wild type (WT) and whole-body knockout 129S6

457 (KO) male mice at 10 months of age. Yellow arrowheads point to the stained macrophages.

458 Scale bars $50 \mu \mathrm{m}$. (B) The number of Iba1 positive cell was normalized to each islet's area size

459 (WT, n=21; KO, n=28). (C) Left panel: Visualized imaging mass cytometry (IMC) image of KO

460 male mouse stained with F4/80 (red), insulin (green), DNA (blue), CD68 (magenta), and CD163

461 (yellow). Contrast staining was performed with Ruthenium (cyan). Middle panel: cells were

462 masked, and the islet area was gated. Right panel: Scatter plot of F4/80, CD163, and CD68.

463 IL-1 $\beta$ was shown in the heatmap. (D) Trichrome-Masson staining of the islets from WT and KO

464 male mice at 10 months of age. Collagen fibers are stained in blue. Scale bars $50 \mu \mathrm{m}$. (E) The

465 blue-colored area was normalized to each islet's area size (WT, n=33; KO, n=34). Data are

466 shown in mean $\pm \mathrm{SEM}, * \mathrm{P}<0.05$, **** $\mathrm{P}<0.001$

468 Figure 6. Hypervascularization in the islets Wolfram syndrome mouse model 
469 (A) Representative immunofluorescent images of islets from Wfs 1 wild type (WT) and

470 whole-body knockout 129S6 (KO) male mice at 10 months of age. Scale bars $50 \mu \mathrm{m}$. (B)

471 Quantification of endothelial cell marker (CD31) positive area and islet area composition (WT,

$472 \mathrm{n}=33 ; \mathrm{KO}, \mathrm{n}=34)$. Data are shown as mean $\pm \mathrm{SEM}, * * * * \mathrm{P}<0.001$.

474 Figure 7. The vicious cycle of inflammation and ER stress accelerates the progression of

475 diabetes in Wolfram syndrome

476 Schematic of the relationship between ER stress and sterile inflammation in Wolfram syndrome

477 (WS). Diabetes in WS is caused by pathogenic ER stress-induced pancreatic $\beta$-cell apoptosis.

478 Hyperglycemic conditions of WFS1-deficient pancreatic $\beta$-cells enhance pathogenic ER stress

479 and induce sterile inflammation. Experimental high-glucose condition induces pro-inflammatory

480 cytokine gene transcription via the PERK pathway and enhances TXNIP-mediated IL-1 $\beta$

481 processing through the PERK and IRE1 $\alpha$ pathways. This high-cytokine condition accelerates ER

482 stress-mediated cell death and upregulates the pro-inflammatory cytokine gene expression in

483 WFS1-deficient pancreatic $\beta$-cells. Secreted chemokines or the hypervascularized environment in

484 the WS islets may cause cell-nonautonomous pancreatic $\beta$-cell inflammation, including

485 M1-macrophage infiltration. 


\section{Acknowledgment}

490 the Rare Genetic Disorders, the Snow Foundation, the Unravel Wolfram Syndrome Fund, the

491 Stowe Fund, the Eye Hope Foundation, the Feiock Fund, Ontario Wolfram League, Associazione

492 Gentian - Sindrome di Wolfram Italia, Alianza de Familias Afectadas por el Sindrome Wolfram

493 Spain, Wolfram syndrome UK, and Association Syndrome de Wolfram France. F. Urano also

494 thanks all the members of the Washington University Wolfram Syndrome Study, Research

495 Clinic, and WFS1 Clinic at the Washington University Medical Center for their support

496 (https://wolframsyndrome.wustl.edu) and all the participants in the Wolfram syndrome

497 International Registry and Clinical Study, Research Clinic, and Clinical Trials for their time and

498 efforts We acknowledge Diane Bender and Kohei Omachi (both in Washington University in St.

499 Louis) for their skilled technical supports and Kohsuke Kanekura (Tokyo Medical University)

500 for his critical review of the manuscript. The authors are grateful to Cris Brown (Washington

501 University in St. Louis) for her general support. This work was supported, in part, by the Bursky

502 Center for Human Immunology and Immunotherapy Programs at Washington University in St.

503 Louis, Immunomonitoring Laboratory. We are grateful for the critical review and editing

504 assistance provided by InPrint: A Scientific Communication Network at Washington University

505 in St. Louis. 


\section{Conflict of Interest}

510 Author F. Urano is a Founder and President of CURE4WOLFRAM, INC and employed by it.

511 The remaining authors declare that the research was conducted in the absence of any commercial

512 or financial relationships that could be construed as a potential conflict of interest. F. Urano is an 513 inventor of three patents related to the treatment of Wolfram syndrome, SOLUBLE MANF IN

514 PANCREATIC BETA CELL DISORDERS (US 9,891,231) and TREATMENT FOR

515 WOLFRAM SYNDROME AND OTHER ER STRESS DISORDERS (US 10,441,574 and US

$51610,695,324)$.

518 Funding

519 This work was partly supported by the grants from the National Institutes of Health (NIH)/NIDDK

520 (DK112921, DK020579). SM was supported by Manpei Suzuki Diabetes Foundation and Japan

521 Society for the Promotion of Science (JSPS) Overseas Research Fellowships.

\section{Author contribution}

524 S.M. and F.U. conceived the project. S.M. designed the experiments. S.M. and L.B. performed

525 the experiments, and S.M., L.B., and C.O. analyzed the data. F.U. supervised the work. All 526 authors participated in writing, editing, and reviewing the manuscript. 


\section{References}

530 1. Urano F. Wolfram Syndrome: Diagnosis, Management, and Treatment. Current diabetes reports. 2016 Jan;16(1):6. doi:10.1007/s11892-015-0702-6. Cited in: Pubmed; PMID 26742931.

2. de Heredia ML, Cleries R, Nunes V. Genotypic classification of patients with Wolfram

534 syndrome: insights into the natural history of the disease and correlation with phenotype. Genet

535 Med. 2013 Jul;15(7):497-506. doi:10.1038/gim.2012.180. Cited in: Pubmed; PMID 23429432.

3. Barrett TG, Bundey SE, Macleod AF. Neurodegeneration and diabetes: UK nationwide study of Wolfram (DIDMOAD) syndrome. Lancet. 1995 December 2, 1995;346:1458-63.

542 Permutt MA. A gene encoding a transmembrane protein is mutated in patients with diabetes

543 mellitus and optic atrophy (Wolfram syndrome). Nature Genetics. 1998;20:143-148.

544 doi:10.1038/2441.

5. Lu S, Kanekura K, Hara T, Mahadevan J, Spears LD, Oslowski CM, Martinez R,

547 Yamazaki-Inoue M, Toyoda M, Neilson A, Blanner P, Brown CM, Semenkovich CF, Marshall

548 BA, Hershey T, Umezawa A, Greer PA, Urano F. A calcium-dependent protease as a potential

549 therapeutic target for Wolfram syndrome. Proceedings of the National Academy of Sciences. 2014;111(49):E5292-E5301. doi:10.1073/pnas.1421055111.

552 6. Fonseca SG, Ishigaki S, Oslowski CM, Lu S, Lipson KL, Ghosh R, Hayashi E, Ishihara H,

553 Oka Y, Permutt MA, Urano F. Wolfram syndrome 1 gene negatively regulates ER stress

554 signaling in rodent and human cells [Research Support, N.I.H., Extramural

555 Research Support, Non-U.S. Gov't]. The Journal of clinical investigation. 2010

556 Mar;120(3):744-55. eng. Epub 2010/02/18. doi:10.1172/JCI39678. Cited in: Pubmed; PMID 55720160352.

559 7. Fonseca SG, Fukuma M, Lipson KL, Nguyen LX, Allen JR, Oka Y, Urano F. WFS1 is a novel 560 component of the unfolded protein response and maintains homeostasis of the endoplasmic 
reticulum in pancreatic beta-cells [Research Support, N.I.H., Extramural

562 Research Support, Non-U.S. Gov't]. J Biol Chem. 2005 Nov 25;280(47):39609-15. Epub

563 2005/10/01. doi:10.1074/jbc.M507426200. Cited in: Pubmed; PMID 16195229.

8. Hetz C, Papa FR. The Unfolded Protein Response and Cell Fate Control. Molecular cell. 2018 Jan 18;69(2):169-181. doi:10.1016/j.molcel.2017.06.017. Cited in: Pubmed; PMID 29107536.

9. Zhang K, Kaufman RJ. From endoplasmic-reticulum stress to the inflammatory response. Nature. 2008 Jul 24;454(7203):455-62. eng. Cited in: Pubmed; PMID 18650916.

10. Liu T, Zhang L, Joo D, Sun SC. NF-kappaB signaling in inflammation. Signal Transduct 29158945.

11. Garg AD, Kaczmarek A, Krysko O, Vandenabeele P, Krysko DV, Agostinis P. ER stress-induced inflammation: does it aid or impede disease progression? Trends Mol Med. 2012 Oct;18(10):589-98. Epub 2012/08/14. doi:10.1016/j.molmed.2012.06.010. Cited in: Pubmed; PMID 22883813.

12. Yong J, Johnson JD, Arvan P, Han J, Kaufman RJ. Therapeutic opportunities for pancreatic doi:10.1038/s41574-021-00510-4. Cited in: Pubmed; PMID 34163039.

13. Eguchi K, Nagai R. Islet inflammation in type 2 diabetes and physiology. The Journal of clinical investigation. 2017 Jan 3;127(1):14-23. Epub 2017/01/04. doi:10.1172/JCI88877. Cited in: Pubmed; PMID 28045399.

14. Donath MY, Shoelson SE. Type 2 diabetes as an inflammatory disease. Nature reviews Immunology. 2011 Feb;11(2):98-107. eng. Epub 2011/01/15. doi:nri2925 [pii] 
syndrome 1 gene regulates pathways maintaining beta-cell health and survival. Lab Invest. 2020

Feb 14. Epub 2020/02/16. doi:10.1038/s41374-020-0408-5. Cited in: Pubmed; PMID 32060407.

16. De Franco E, Flanagan SE, Yagi T, Abreu D, Mahadevan J, Johnson MB, Jones G, Acosta F,

Mulaudzi M, Lek N, Oh V, Petz O, Caswell R, Ellard S, Urano F, Hattersley AT. Dominant ER

Stress-Inducing WFS1 Mutations Underlie a Genetic Syndrome of Neonatal/Infancy-Onset Jul;66(7):2044-2053. Epub 2017/05/05. doi:10.2337/db16-1296. Cited in: Pubmed; PMID 60128468959.

17. Nguyen LD, Fischer TT, Abreu D, Arroyo A, Urano F, Ehrlich BE. Calpain inhibitor and ibudilast rescue beta cell functions in a cellular model of Wolfram syndrome. Proc Natl Acad Sci U S A. 2020 Jul 6. Epub 2020/07/08. doi:10.1073/pnas.2007136117. Cited in: Pubmed; PMID 32632005. by islets in health and diabetes: cellular origin, regulation and function. Trends in endocrinology 610 and metabolism: TEM. 2010 May;21(5):261-7. eng. Epub 2010/01/26. 611 doi:S1043-2760(09)00221-5 [pii]

612 10.1016/j.tem.2009.12.010. Cited in: Pubmed; PMID 20096598.

614 19. Oslowski CM, Hara T, O'Sullivan-Murphy B, Kanekura K, Lu S, Hara M, Ishigaki S, Zhu LJ, 615 Hayashi E, Hui ST, Greiner D, Kaufman RJ, Bortell R, Urano F. Thioredoxin-interacting protein 616 mediates ER stress-induced beta cell death through initiation of the inflammasome [Research 617 Support, N.I.H., Extramural

618 Research Support, Non-U.S. Gov't]. Cell Metab. 2012 Aug 8;16(2):265-73. eng. Epub 619 2012/08/14. doi:10.1016/j.cmet.2012.07.005. Cited in: Pubmed; PMID 22883234.

621 20. Lerner AG, Upton JP, Praveen PV, Ghosh R, Nakagawa Y, Igbaria A, Shen S, Nguyen V, 622 Backes BJ, Heiman M, Heintz N, Greengard P, Hui S, Tang Q, Trusina A, Oakes SA, Papa FR. 623 IRE1alpha induces thioredoxin-interacting protein to activate the NLRP3 inflammasome and 624 promote programmed cell death under irremediable ER stress [Research Support, N.I.H., 
Extramural

626 Research Support, Non-U.S. Gov't]. Cell Metab. 2012 Aug 8;16(2):250-64. eng. Epub 627 2012/08/14. doi:10.1016/j.cmet.2012.07.007. Cited in: Pubmed; PMID 22883233.

21. Shalev A. Minireview: Thioredoxin-interacting protein: regulation and function in the 630 pancreatic beta-cell. Mol Endocrinol. 2014 Aug;28(8):1211-20. Epub 2014/06/10. 631 doi:10.1210/me.2014-1095. Cited in: Pubmed; PMID 24911120.

22. Koks S, Soomets U, Paya-Cano JL, Fernandes C, Luuk H, Plaas M, Terasmaa A, Tillmann V, 634 Noormets K, Vasar E, Schalkwyk LC. Wfs1 gene deletion causes growth retardation in mice and interferes with the growth hormone pathway. Physiol Genomics. 2009 May 13;37(3):249-59. doi:10.1152/physiolgenomics.90407.2008. Cited in: Pubmed; PMID 19293327. M, Halban P, Portha B, Serradas P. Islet inflammation and fibrosis in a spontaneous model of type 2 diabetes, the GK rat. Diabetes. 2006 Jun;55(6):1625-33. Epub 2006/05/30. doi:10.2337/db05-1526. Cited in: Pubmed; PMID 16731824. vascular endothelial growth factor-A signaling, promotes beta cell regeneration. Cell Metab. 2014 Mar 4;19(3):498-511. Epub 2014/02/25. doi:10.1016/j.cmet.2014.02.001. Cited in:

647 Pubmed; PMID 24561261.

25. Agudo J, Ayuso E, Jimenez V, Casellas A, Mallol C, Salavert A, Tafuro S, Obach M, Ruzo A,

650 Moya M, Pujol A, Bosch F. Vascular endothelial growth factor-mediated islet 651 hypervascularization and inflammation contribute to progressive reduction of beta-cell mass. 652 Diabetes. 2012 Nov;61(11):2851-61. Epub 2012/09/11. doi:10.2337/db12-0134. Cited in: 653 Pubmed; PMID 22961079.

655 26. Brissova M, Shostak A, Shiota M, Wiebe PO, Poffenberger G, Kantz J, Chen Z, Carr C, 656 Jerome WG, Chen J, Baldwin HS, Nicholson W, Bader DM, Jetton T, Gannon M, Powers AC. 
657 Pancreatic Islet Production of Vascular Endothelial Growth Factor-A Is Essential for Islet

658 Vascularization, Revascularization, and Function. Diabetes. 2006;55(11):2974-2985.

659 doi:10.2337/db06-0690.

27. Maedler K, Sergeev P, Ris F, Oberholzer J, Joller-Jemelka HI, Spinas GA, Kaiser N, Halban PA, Donath MY. Glucose-induced beta cell production of IL-1beta contributes to glucotoxicity in

663 human pancreatic islets. The Journal of clinical investigation. 2002 Sep;110(6):851-60. eng. 664 Epub 2002/09/18. doi:10.1172/JCI15318. Cited in: Pubmed; PMID 12235117.

28. Calderon B, Carrero JA, Ferris ST, Sojka DK, Moore L, Epelman S, Murphy KM, Yokoyama WM, Randolph GJ, Unanue ER. The pancreas anatomy conditions the origin and properties of resident macrophages. J Exp Med. 2015 Sep 21;212(10):1497-512. Epub 2015/09/09. doi:10.1084/jem.20150496. Cited in: Pubmed; PMID 26347472.

29. Ying W, Lee YS, Dong Y, Seidman JS, Yang M, Isaac R, Seo JB, Yang BH, Wollam J, Riopel M, McNelis J, Glass CK, Olefsky JM, Fu W. Expansion of Islet-Resident Macrophages Leads to Inflammation Affecting beta Cell Proliferation and Function in Obesity. Cell Metab. 2019 Feb 5;29(2):457-474 e5. Epub 2019/01/01. doi:10.1016/j.cmet.2018.12.003. Cited in: Pubmed; PMID 67530595478.

30. Ehses JA, Perren A, Eppler E, Ribaux P, Pospisilik JA, Maor-Cahn R, Gueripel X, MY. Increased number of islet-associated macrophages in type 2 diabetes. Diabetes. 2007 680 Sep;56(9):2356-70. Epub 2007/06/21. doi:10.2337/db06-1650. Cited in: Pubmed; PMID 68117579207.

683 31. Carrero JA, McCarthy DP, Ferris ST, Wan X, Hu H, Zinselmeyer BH, Vomund AN, Unanue 684 ER. Resident macrophages of pancreatic islets have a seminal role in the initiation of 685 autoimmune diabetes of NOD mice. Proc Natl Acad Sci U S A. 2017 Nov 686 28;114(48):E10418-E10427. Epub 2017/11/15. doi:10.1073/pnas.1713543114. Cited in: 687 Pubmed; PMID 29133420. 

islet-resident macrophage is in an inflammatory state and senses microbial products in blood. $\mathrm{J}$ Exp Med. 2017 Aug 7;214(8):2369-2385. Epub 2017/06/21. doi:10.1084/jem.20170074. Cited in: Pubmed; PMID 28630088.

694 33. Ginhoux F, Jung S. Monocytes and macrophages: developmental pathways and tissue 695 homeostasis. Nat Rev Immunol. 2014 Jun;14(6):392-404. Epub 2014/05/24. doi:10.1038/nri3671. 696 Cited in: Pubmed; PMID 24854589. CCL2 in insulin-producing cells of transgenic mice promotes mobilization of myeloid cells from the bone marrow, marked insulitis, and diabetes. Diabetes. 2008 Nov;57(11):3025-33. Epub 2008/07/18. doi:10.2337/db08-0625. Cited in: Pubmed; PMID 18633103.

35. Ghosh R, Lipson KL, Sargent KE, Mercurio AM, Hunt JS, Ron D, Urano F. Transcriptional regulation of VEGF-A by the unfolded protein response pathway [Research Support, N.I.H., 705 Extramural

706 Research Support, Non-U.S. Gov't]. PloS one. 2010;5(3):e9575. eng. Epub 2010/03/12. doi:10.1371/journal.pone.0009575. Cited in: Pubmed; PMID 20221394.

36. Zinselmeyer BH, Vomund AN, Saunders BT, Johnson MW, Carrero JA, Unanue ER. The resident macrophages in murine pancreatic islets are constantly probing their local environment,

711 capturing beta cell granules and blood particles. Diabetologia. 2018 Jun;61(6):1374-1383. Epub

712 2018/03/29. doi:10.1007/s00125-018-4592-4. Cited in: Pubmed; PMID 29589072.

714 37. Shanmugam N, Reddy MA, Guha M, Natarajan R. High glucose-induced expression of 715 proinflammatory cytokine and chemokine genes in monocytic cells. Diabetes. 2003 716 May;52(5):1256-64. Epub 2003/04/30. doi:10.2337/diabetes.52.5.1256. Cited in: Pubmed; PMID $717 \quad 12716761$.

719 38. Spranger J, Kroke A, Mohlig M, Hoffmann K, Bergmann MM, Ristow M, Boeing H, Pfeiffer 720 AF. Inflammatory cytokines and the risk to develop type 2 diabetes: results of the prospective 
721 population-based European Prospective Investigation into Cancer and Nutrition (EPIC)-Potsdam

722 Study. Diabetes. 2003 Mar;52(3):812-7. Epub 2003/02/28. doi:10.2337/diabetes.52.3.812. Cited

723 in: Pubmed; PMID 12606524.

39. Pradhan AD, Manson JE, Rifai N, Buring JE, Ridker PM. C-reactive protein, interleukin 6,

and risk of developing type 2 diabetes mellitus. JAMA. 2001 Jul 18;286(3):327-34. Epub 2001/07/24. doi:10.1001/jama.286.3.327. Cited in: Pubmed; PMID 11466099.

40. Panfili E, Mondanelli G, Orabona C, Belladonna ML, Gargaro M, Fallarino F, Orecchini E,

730 Prontera P, Proietti E, Frontino G, Tirelli E, Iacono A, Vacca C, Puccetti P, Grohmann U,

731 Esposito S, Pallotta MT. Novel mutations in the WFS1 gene are associated with Wolfram

732 syndrome and systemic inflammation. Hum Mol Genet. 2021 Mar 9. Epub 2021/03/12. 733 doi:10.1093/hmg/ddab040. Cited in: Pubmed; PMID 33693650.

41. Abreu D, Stone SI, Pearson TS, Bucelli RC, Simpson AN, Hurst S, Brown CM, Kries K,

736 Onwumere C, Gu H, Hoekel J, Tychsen L, Van Stavern GP, White NH, Marshall BA, Hershey T,

737 Urano F. A phase Ib/Ila clinical trial of dantrolene sodium in patients with Wolfram syndrome. 738 JCI Insight. 2021 Aug 9;6(15). Epub 2021/06/30. doi:10.1172/jci.insight.145188. Cited in: 739 Pubmed; PMID 34185708.

741 42. Maxwell KG, Augsornworawat P, Velazco-Cruz L, Kim MH, Asada R, Hogrebe NJ,

742 Morikawa S, Urano F, Millman JR. Gene-edited human stem cell-derived beta cells from a 743 patient with monogenic diabetes reverse preexisting diabetes in mice. Science translational 744 medicine. 2020 Apr 22;12(540). Epub 2020/04/24. doi:10.1126/scitranslmed.aax9106. Cited in: 745 Pubmed; PMID 32321868.

747 43. Rehman A, Pacher P, Hasko G. Role of Macrophages in the Endocrine System. Trends 748 Endocrinol Metab. 2021 Apr;32(4):238-256. Epub 2021/01/19. doi:10.1016/j.tem.2020.12.001. 749 Cited in: Pubmed; PMID 33455863.

751 44. Okita N, Higami Y, Fukai F, Kobayashi M, Mitarai M, Sekiya T, Sasaki T. Modified Western 752 blotting for insulin and other diabetes-associated peptide hormones. Sci Rep. 2017 Jul 
bioRxiv preprint doi: https://doi.org/10.1101/2022.02.09.479773; this version posted February 9, 2022. The copyright holder for this preprint (which was not certified by peer review) is the author/funder, who has granted bioRxiv a license to display the preprint in perpetuity. It is made available under aCC-BY-NC 4.0 International license.

753 31;7(1):6949. Epub 2017/08/02. doi:10.1038/s41598-017-04456-4. Cited in: Pubmed; PMID

75428761041.

755

756 
A

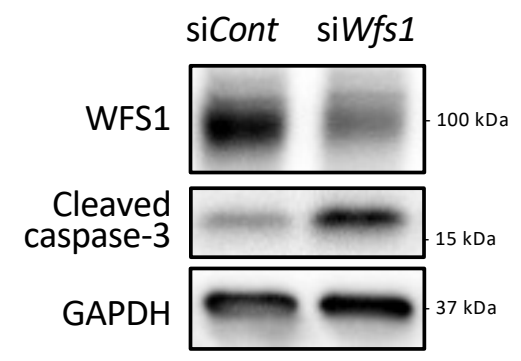

C

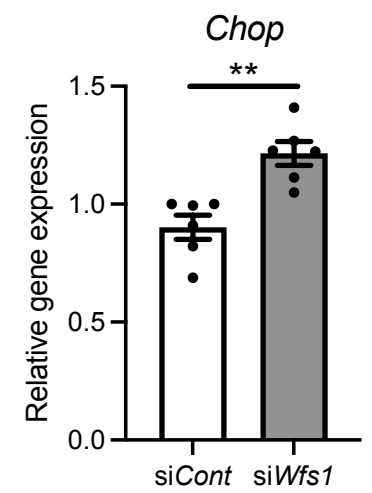

$c$
B

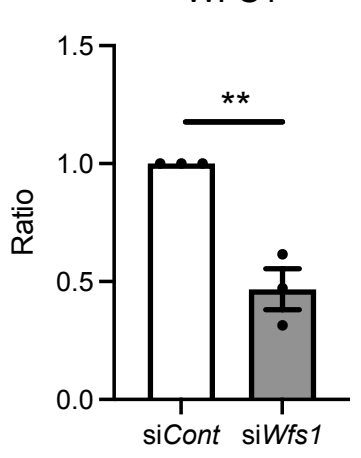

Cleaved caspase-3

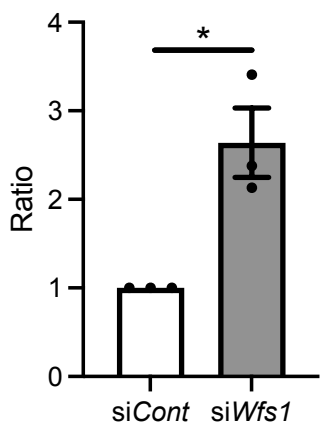

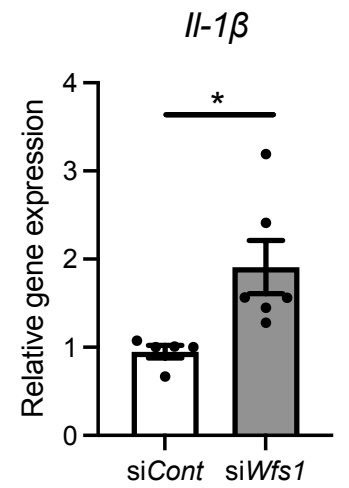
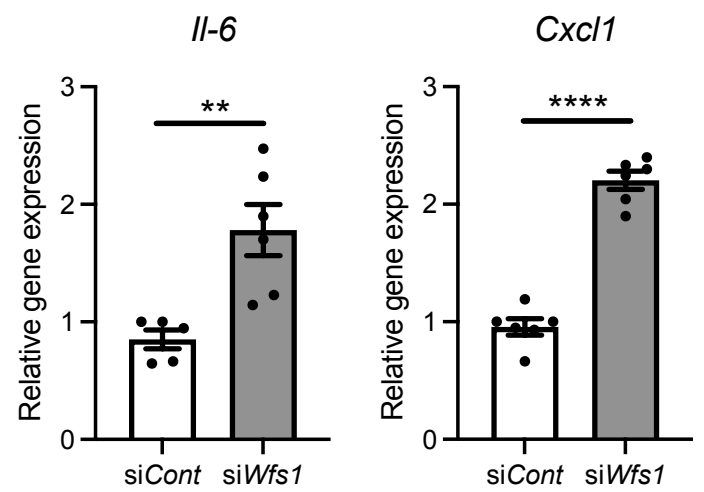
bioRxiv preprint doi: https://doi.org/10.1101/2022.02.09.479773; this version posted February 9, 2022. The copyright holder for this preprint (which was not certified by peer review) is the author/funder, who has granted bioRxiv a license to display the preprint in perpetuity. It is made available under aCC-BY-NC 4.0 International license.

A

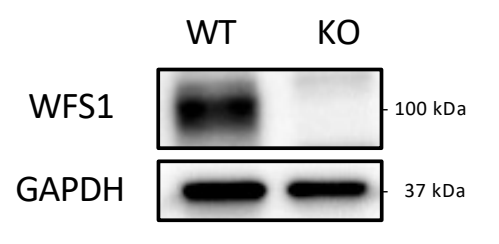

D

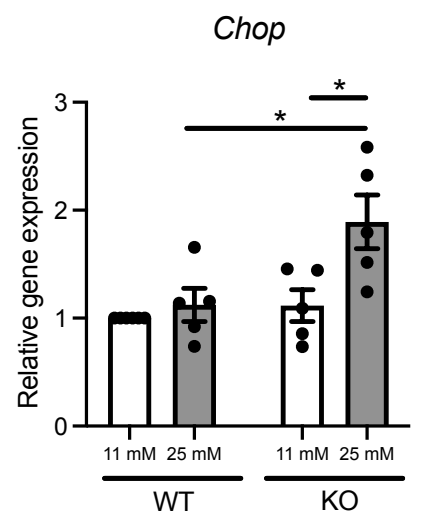

$\mathrm{E}$

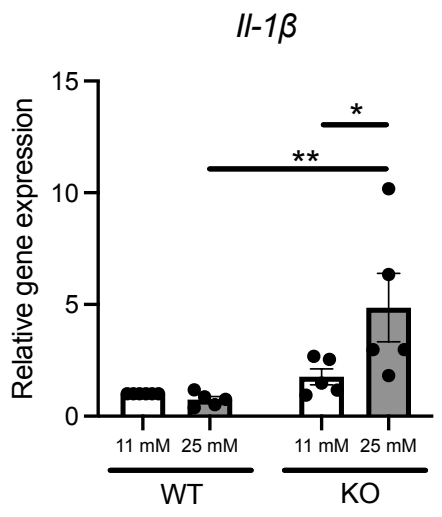

\section{B}
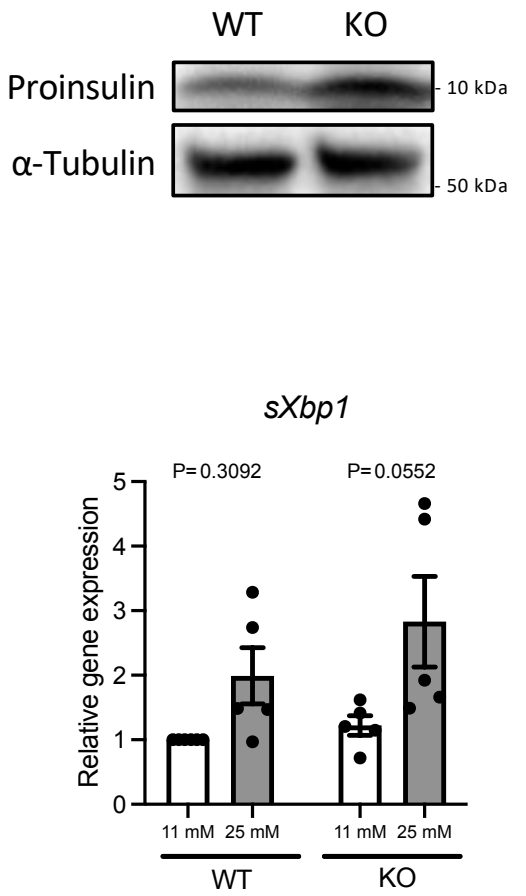

II-6

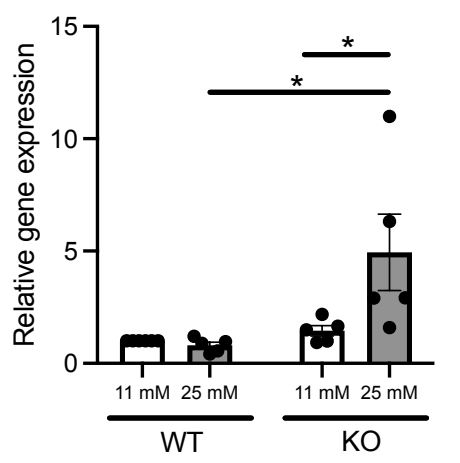

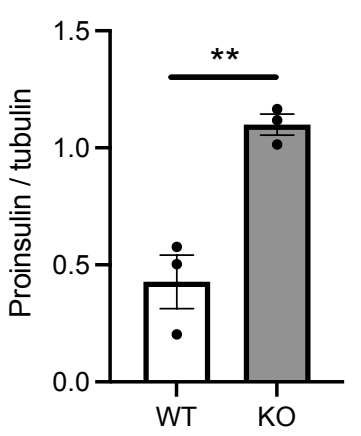

Bip
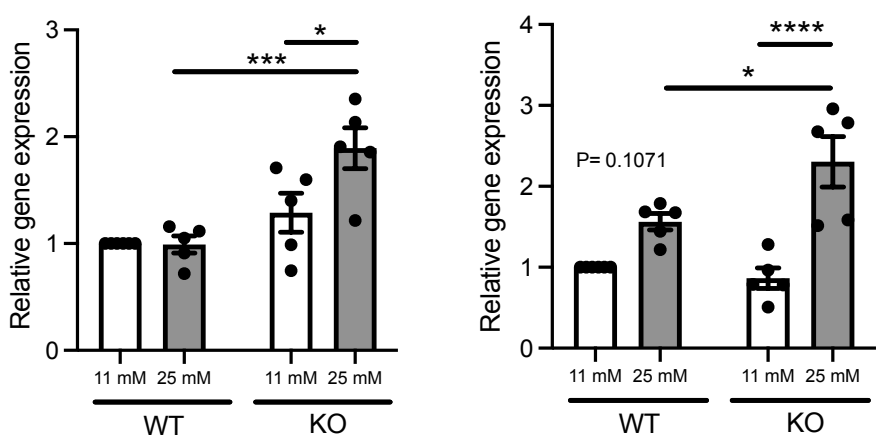

Ccl2
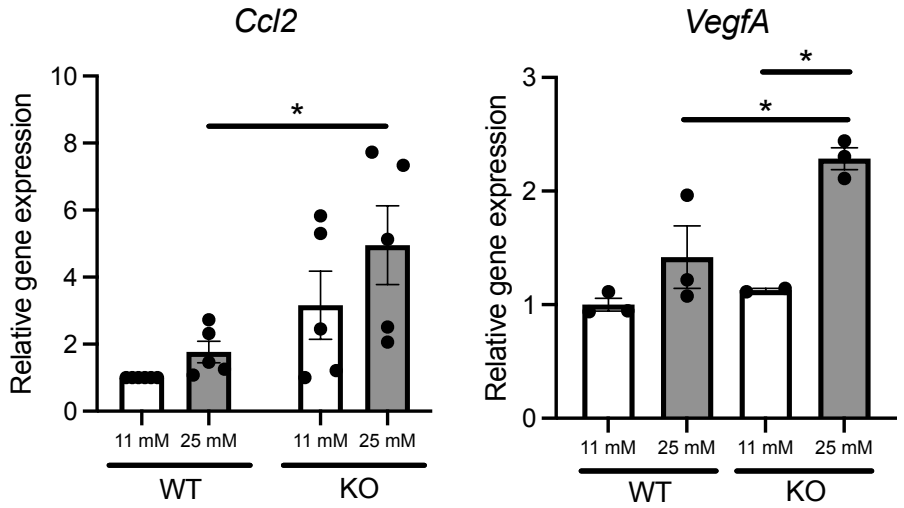
A

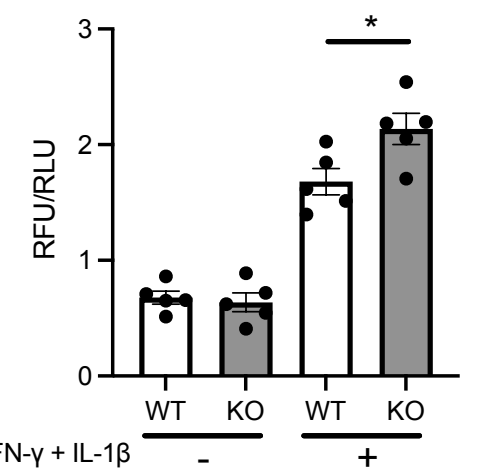

B
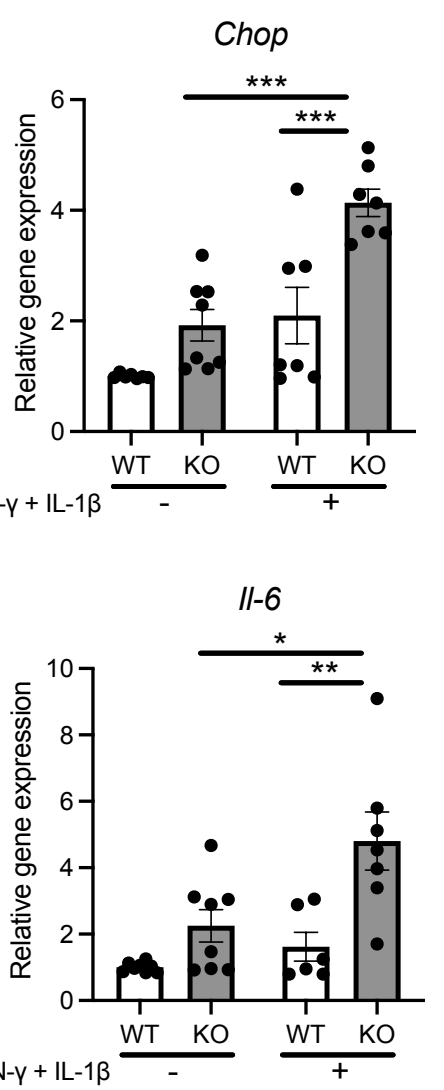
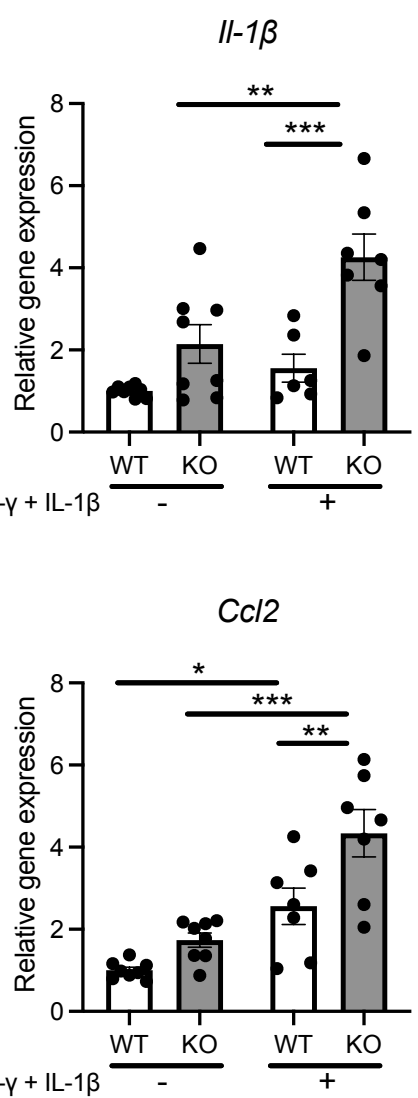
bioRxiv preprint doi: https://doi.org/10.1101/2022.02.09.479773; this version posted February 9.2022 . The copyright holder for this preprint (which was not certified by peer review) is the author/funder, who has granted bioRxiv a license to display the preprint in perpetuity. It is made A available under aCC-BY-NC 4.0 International license.
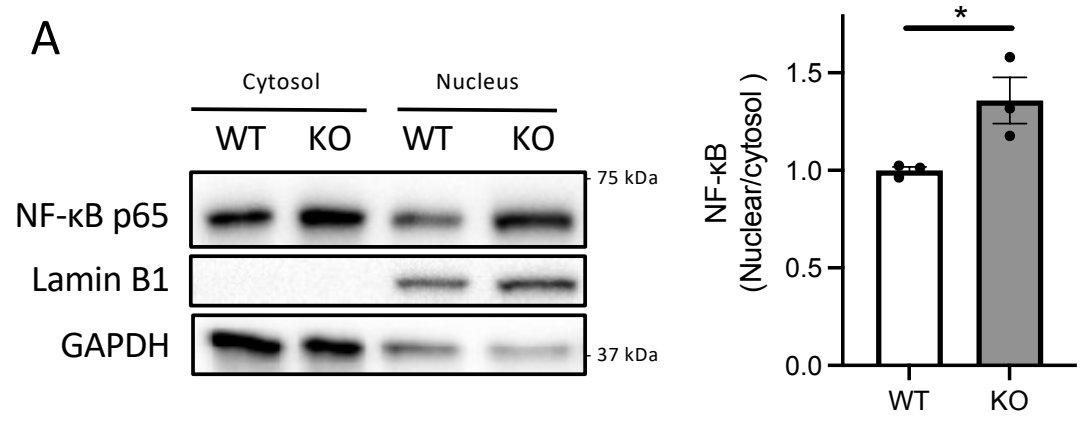

B

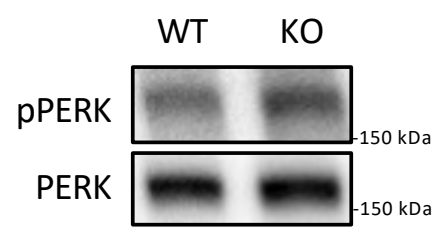

D

siPerk

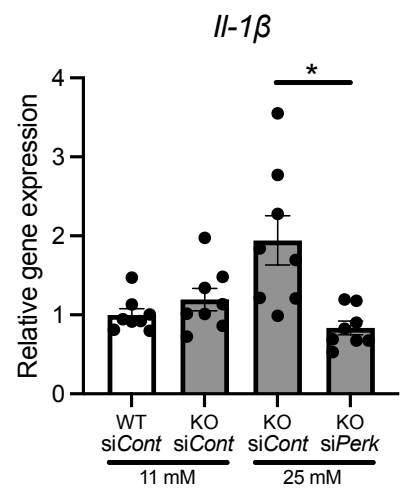

E

siPerk

Txnip

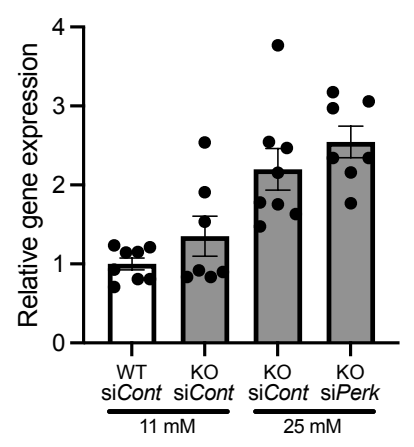

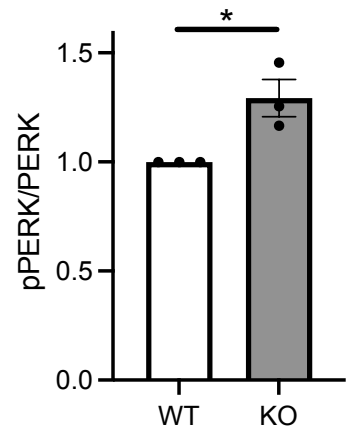

C

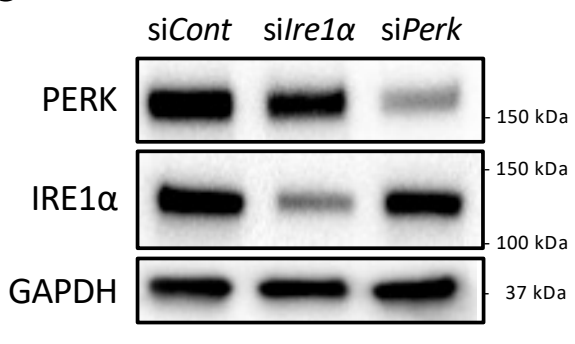

silre1 $\alpha$

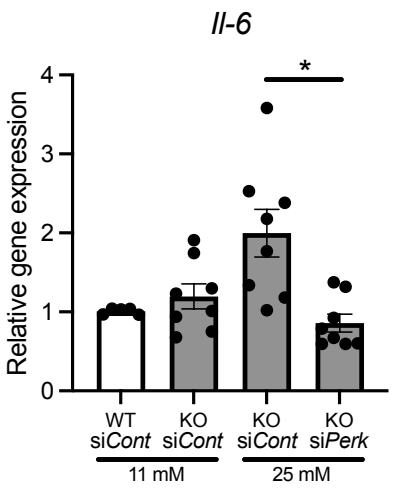

silre1 $\alpha$

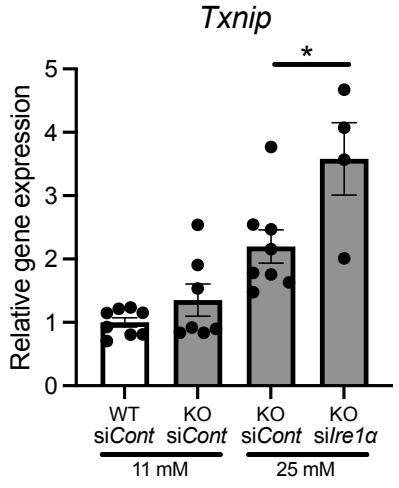

$I-1 \beta$
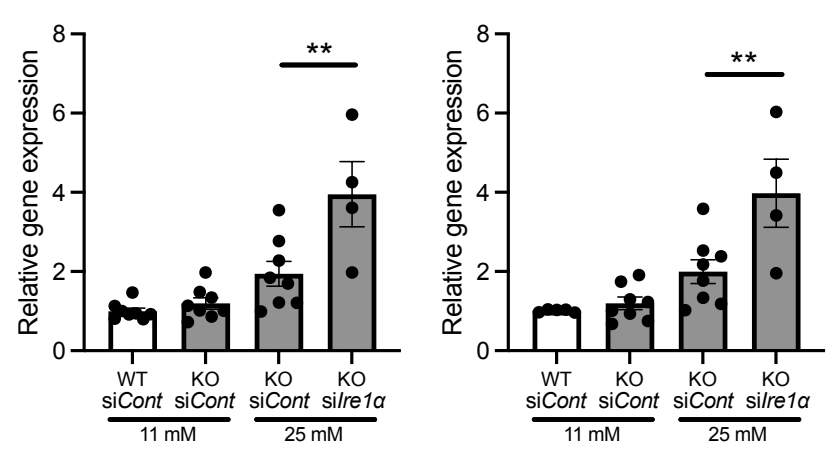

silre1 $\alpha$ + siPerk

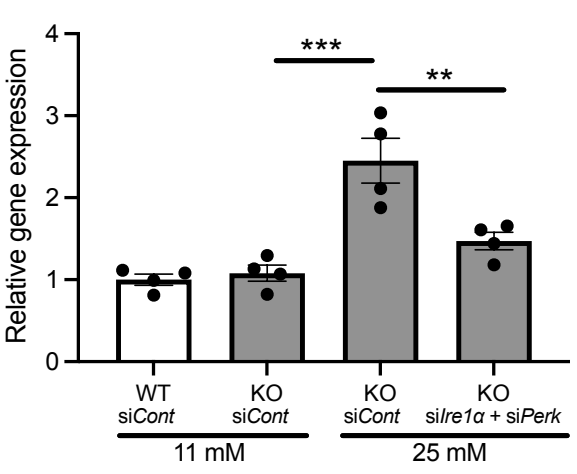


bioRxiv preprint doi: https://doi.org/10.1101/2022.02.09.479773; this version posted February 9, 2022. The copyright holder for this preprint (which was not certified by peer review) is the author/funder, who has granted bioRxiv a license to display the preprint in perpetuity. It is made available under aCC-BY-NC 4.0 International license.
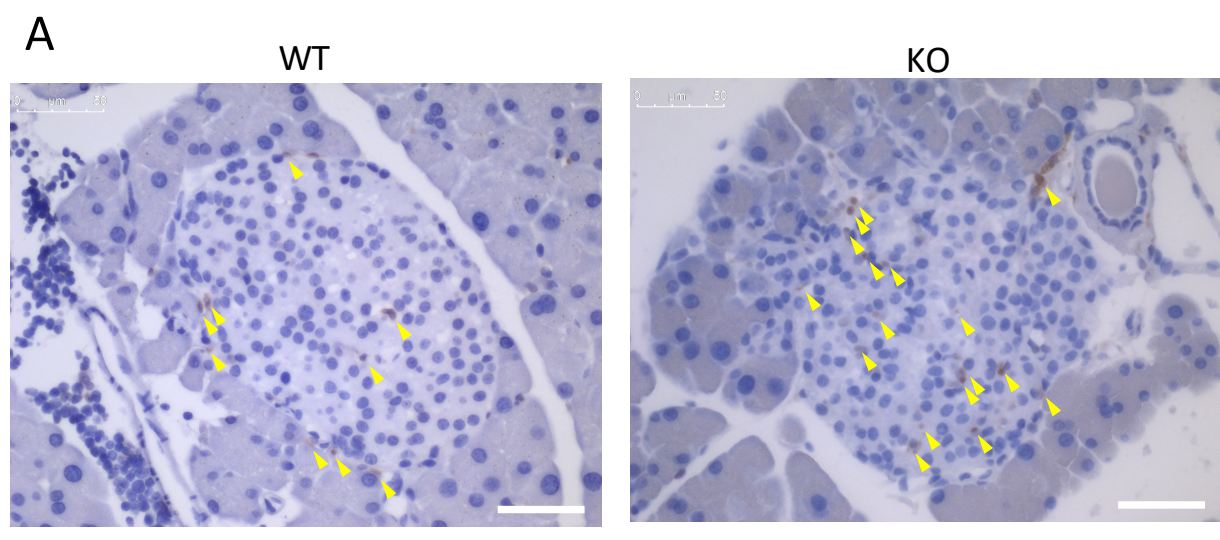

C
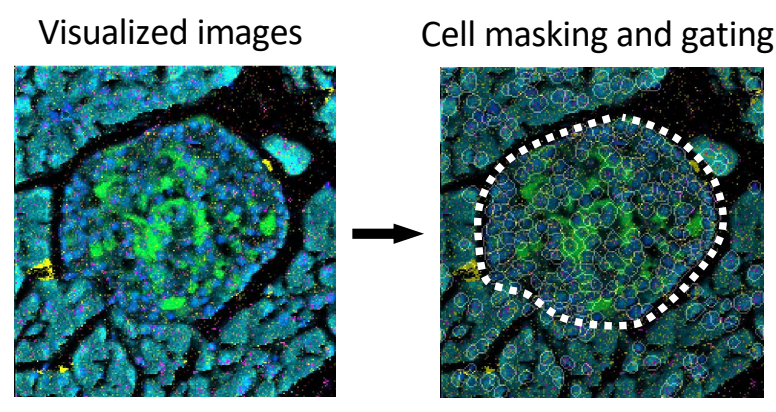

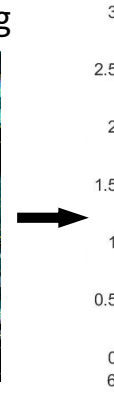

B

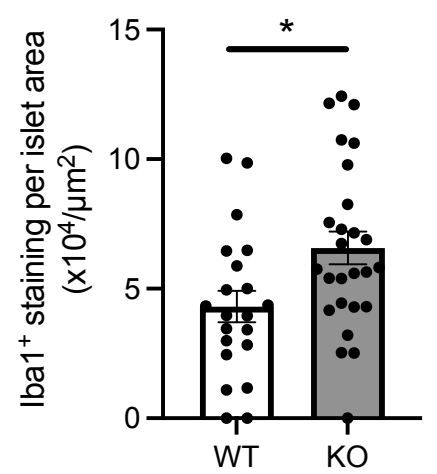

D

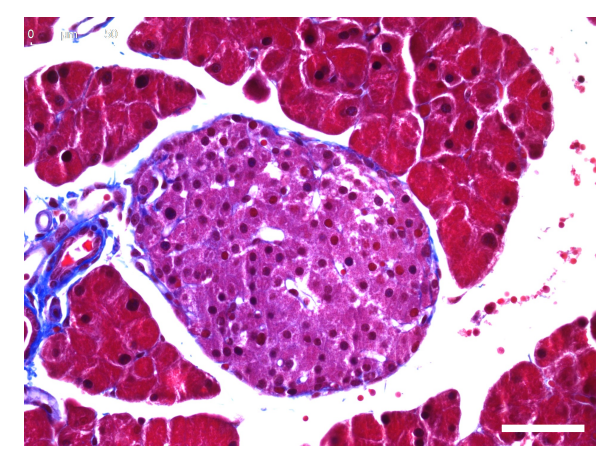

Heatmap IL-1ß

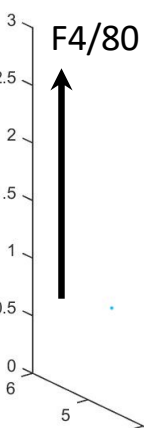

$\mathrm{F} 4 / 80$

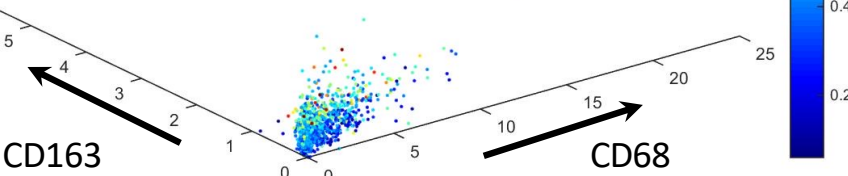

KO

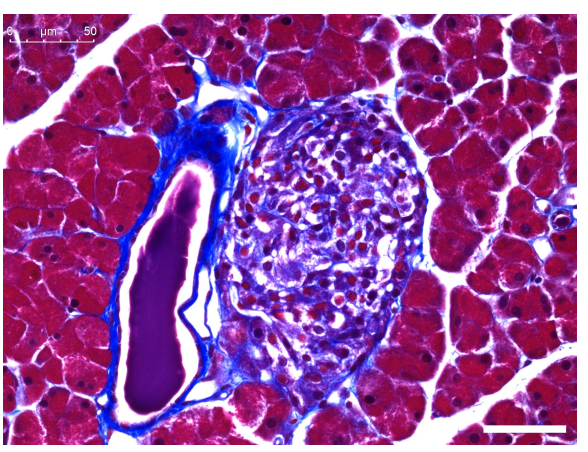

E

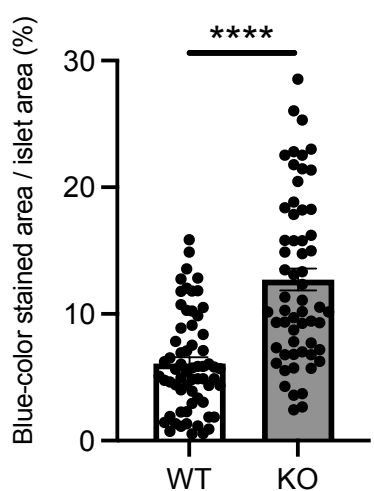


bioRxiv preprint doi: https://doi.org/10.1101/2022.02.09.479773; this version posted February 9,2022 . The copyright holder for this preprint (which was not certified by peer review) is the author/funder, who has granted bioRxiv a license to display the preprint in perpetuity. It is made available under aCC-BY-NC 4.0 International license.

A
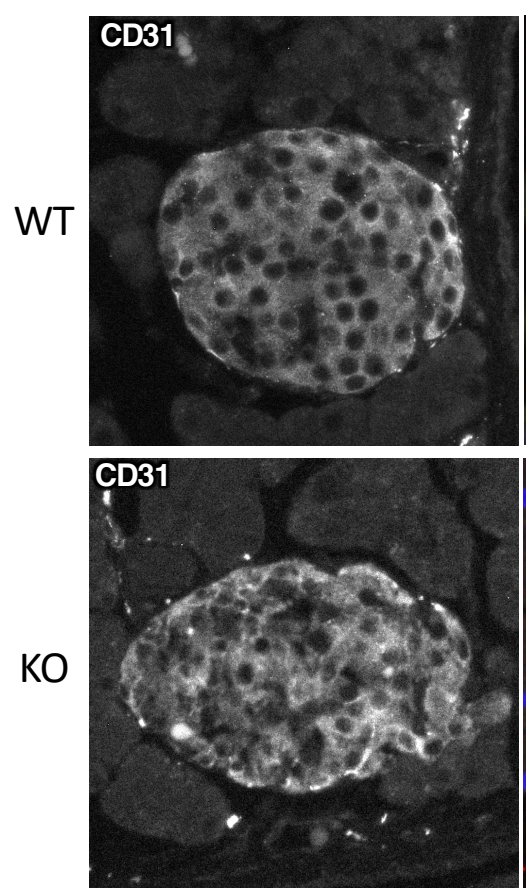

B

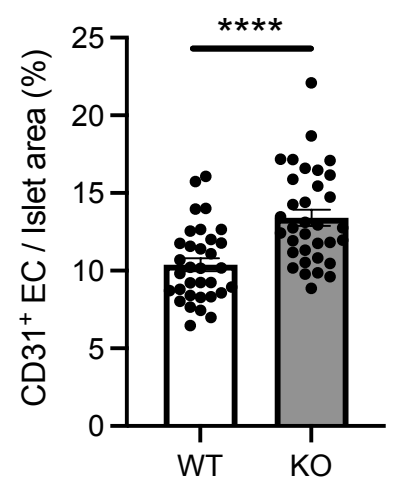




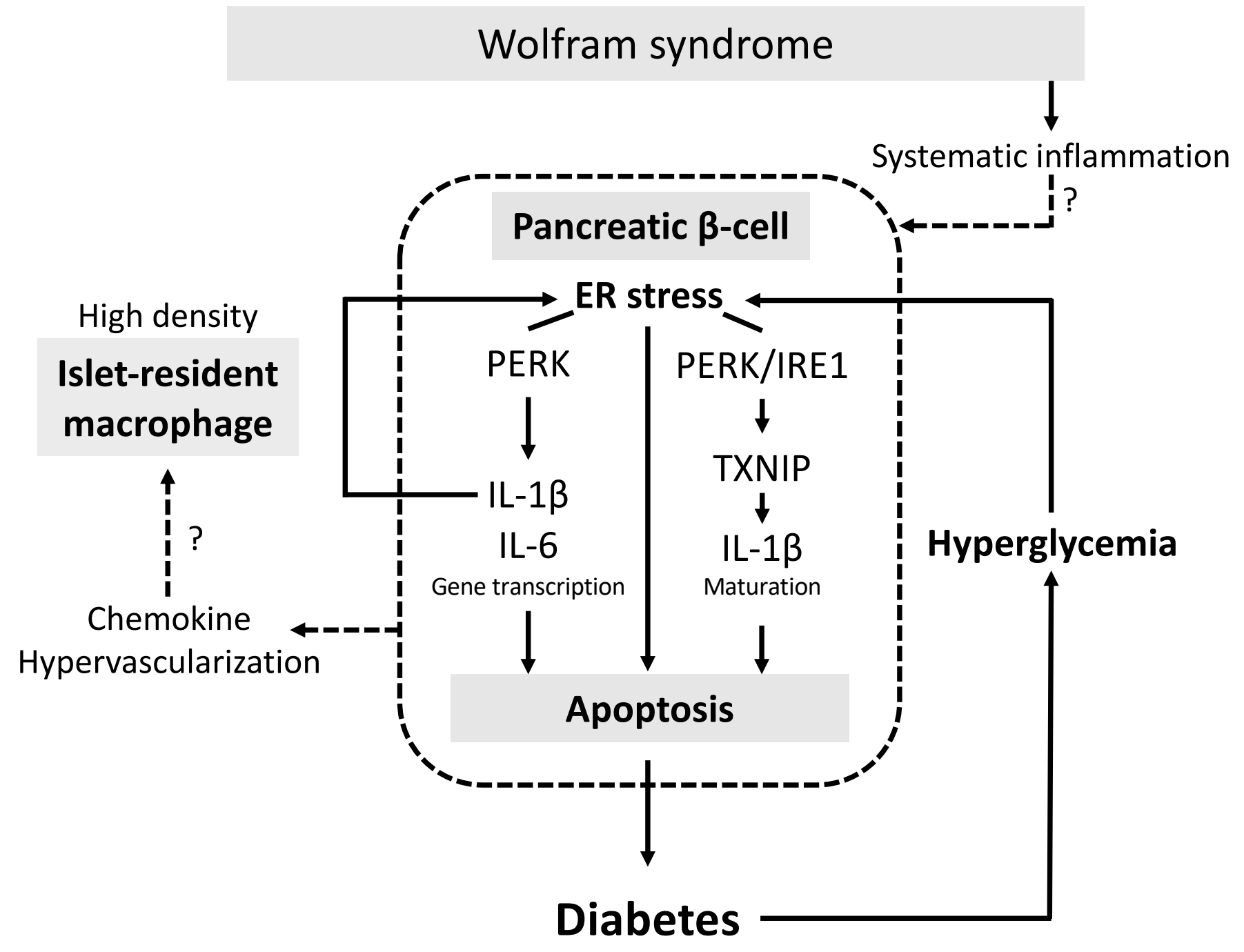

